\title{
DESIGN OF AN AUTOMATIC STERILIZATION GATE TOOL USING PIR MOTION SENSOR
}

\author{
Faiq Fawwaz Amrullah'; Dewi Khairani²; Siti Ummi Masruroh ${ }^{3}$
}

\author{
Physics $^{1}$; Informatics ${ }^{2,3}$ \\ UIN Syarif Hidayatullah Jakarta, Indonesia \\ www.uinjkt.ac.id \\ faiq.fawwaz17@mhs.uinjkt.ac.id ${ }^{1}$; dewi.khairani@uinjkt.ac.id 2 (*); ummi.masruroh@uinjkt.ac.id ${ }^{3}$
}

$(*)$ Corresponding Author

\begin{abstract}
This automatic sterilization gate tool is a simple tool that changes the manual method to a systemized and more efficient way. This tool uses an infrared motion sensor in which there is a main component, namely the PIR (Pyroelectric Infra-Red) sensor, which is a material that reacts to radiation and movement in front of it. This tool also uses a $12 \mathrm{v}$ dc pump which is used to draw out the disinfectant liquid stored in the container. This gate tool is designed using the main material and some additional materials, the automatic gate can discharge about 11 seconds of liquid from objects or people that pass through the sensor range, 11 seconds is the minimum time for this tool to work while a distance of 6 meters is the range from where the sensor is located. From that time it proved that this gate tool has $100 \%$ accuracy and runs well. This gate tool is used every day, turned on from the morning, and turned off at night. Every 17.00 hours this gate tool is always replenished with supplies of disinfectant liquid. The automatic gate has helped the community to reduce the risk of transmission of the coronavirus, it also raises the awareness of the covid-19 pandemic. The whole system is implemented and is tested for real-time operation. It is found working satisfactorily. The gate tool can be further improved by adding a scanning device to perform tracing for passersby.
\end{abstract}

Keywords: Motion Sensor, PIR, Sterilization Pump, DC Pump.

Abstrak- Alat gerbang sterilisasi otomatis ini
merupakan alat sederhana yang mengubah cara
manual menjadi tersistem dan lebih efisien. Alat ini
menggunakan infrared motion sensor yang
didalamnya terdapat komponen utama yaitu sensor
PIR ( Pyroelectric Infra Red) yang merupakan bahan
yang bereaksi terhadap radiasi dan gerakan
didepannya. Alat ini juga menggunakan pompa dc
$12 v$ yang digunakan untuk menarik keluar cairan
disinfektan yang disimpan didalam wadah. Gerbang
ini dirancang dengan menggunakan bahan utama
dan beberapa bahan tambahan, gerbang otomatis
dapat melakukan pelepasan cairan sekitar 11 detik dari benda atau orang yang melewati jangkauan sensor, 11 detik adalah waktu minimum untuk alat ini bekerja sedangkan jarak 6 meter merupakan jangkauan dari tempat sensor berada. Dari waktu tersebut membuktikan bahwa alat ini memliki ketelitian $100 \%$ dan berjalan dengan baik. Alat ini dipakai setiap hari dinyalakan dari pagi dan dimatikan pada malam hari. Setiap jam 17.00 alat ini selalu diisi ulang persediaan cairan disinfektannya. Gerbang otomatis ini telah membantu masyarakat dalam mengurangi risiko penularan virus corona, sekaligus meningkatkan kesadaran akan pandemi Covid-19. Seluruh sistem diterapkan dan diuji untuk operasi waktu yang sesungguhnya. Sistem ini mampu bekerja dengan memuaskan. Gerbang ini dapat lebih ditingkatkan dengan menambahkan perangkat pemindai untuk melakukan penelusuran bagi orang yang lewat.

Kata Kunci: Sensor Gerak, PIR, Pompa Sterilisasi, Pompa DC.

\section{INTRODUCTION}

A lot of electronic equipment is normally performed manually at this time or human effort is still needed to operate the electronic equipment. Such electronic devices are still just for the benefit of humans, but they are not smart. So, to be even better, we need innovation and electronic device growth. In the year 2020, the world is being hit by the outbreak of coronavirus disease in 2019 or we called COVID-19. The virus was first discovered in Wuhan, China on December 31, 2019 (Baskara, 2020). In the presence of the virus, many countries have taken medical measures to save their citizens and to prevent the widespread distribution of COVID-19.

The control of the disease is a top priority across the globe. Due to the current lack of an effective vaccine or specific treatment, disinfection, sanitization, and distancing are considered to be the most suitable steps to reduce the spread of viruses. To fight the epidemic, health organizations around the world have suggested various precautionary 
maneuvers(WHO, 2020), including physical distancing, forced or self-quarantine, and personal hygiene. As the COVID-19 pandemic continues to gain traction around the world, many steps to monitor its spread are being placed in place(Buoite Stella et al., 2020; Tavakoli, Carriere, \& Torabi, 2020). The construction of walkthrough sanitization gates to disinfect passersby and avoid cross-infection inside the premises is one such initiative. These gates, also known as sanitizing or disinfectant rooms, tunnels, cabinets, booths, or partitions, provide 20-30 seconds as individuals pass through them with an overhead shower of disinfectant solution.

Different vendors are currently aggressively marketing them, claiming to kill 99.9 percent of the coronavirus. They have recently been built in public areas, shopping centers, malls, mosques, train stations, hospitals, offices, and factories in different countries. Amid lockdown relaxation in different countries, demand for these walkthrough gates has risen sharply despite several parties still arguing about their effectiveness and safety (Gardezi, Rathore, \& Farooq, 2020).

Hydraulic electric gate systems were the first commercial electric gate systems, and they were designed for dependability and ease of use. However, due to the high cost of the hydraulic system, other firms began to develop more costeffective electromechanical solutions. Automatic gates are used to restrict entry to a restricted area or area within a restricted area. Automatic gates are more widely seen at the facility's entry to monitor vehicular traffic on and off the premises(Florence Ikpeze, Chidiebere Uwaezuoke, Samiat, \& Kareem, Michael, 2019).

In gate management, research by Hamid, Erman, et al.(Hamid et al., 2018) implemented a device that activates the gate without activating the alarm by using a legitimate staff member's QR code pass card. PIR motion sensor, servo motor, Arduino microcontroller, Piezo buzzer, and webcam are among the components. The app is written in VB.NET, and the QR recognition accuracy is about 99 percent. Similar studies about automatic gate also performed by (Asha, Syed Navaz, Jayashree, \& Vijayashree, 2018; Khreasarn \& Hantrakul, 2018) that also feature motion detection.

Several studies on PIR sensors have been carried out. One of them is Gifson and Slamet (Gifson \& Slamet, 2009) who conducted the study research on room monitoring systems long distance with passive infrared sensor based on the AT89S52 microcontroller. The research resulted in a security system that can detect people and will send messages to the owner's cell phone. Lestari (Lestari, 2017) conducted research using the Passive InfraRed Kc7783r sensor and the At89s51 microcontroller in the design of automatic doors. This scheme has been developed and the door can be pushed automatically. The door will switch open and close to the right or left side if an entity approaches the door and is detected by the KC7783R PIR sensor. This device, however, still has a drawback, especially when the door is in the process of closing. The door will reopen automatically if the sensor senses human activity, but this state is only temporary during the initial device activation. This condition doesn't work anymore after a while.

H.T Sukmana, et. al (Sukmana, Farisi, \& Khairani, 2016) built to achieve a system that is inexpensive, effective, reliable, and applicable. The key method works by adding a motion sensor, using a PIR sensor, linked to the Arduino microcontroller, and connecting to the webserver for Twitter notification. The result shows early adoption from the sensor to the internet and social media works well.

Morsalin, et. al through their work (Morsalin et al., 2017), has developed a proposed multi-layer home security system (HSS) that maintains six layers of security. The first protection level uses the NFC tag, the second level uses a secure password scheme, and fingerprint authentication is used in the third level. A Passive Infrared (PIR) motion sensor can run and sound an alarm buzzer if an intruder tries to access the room by breaching the password.

Research by Vasantharao (Vasantharao \& Arifunneesa, 2020) explores the designing and synthesis of temperature detection and automatic sanitization and disinfection tunnel using Arduino Uno. The main objective is to measure and display the temperature when it goes beyond a certain limit. In near future, it can also be used in different industries, companies, and many public places. This paper provides a glimpse of Arduino, working principle, design, and implementation using Arduino. This work was also inspired by the covid19 pandemic situation.

Maurya et. al develop a disinfection tunnel to disinfect external surfaces of COVID-19 virus such as clothes and open body sections in public places. The tunnel has two chambers with three disinfection processes to neutralize the virus. The tunnel is developed under industry-academia collaboration (Maurya et al., 2020). This work's vision is similar to ours which is autonomous and without any human intervention, but more cost needed in material and component.

A low-cost auto gate system was built by Abdul Hadi(Hadi, 2015) to be used as the rear gate for the backyard of the house. The controller used in this research is a smartphone integrated by an android program. The software used for this project is the 
Arduino program and the controller is linking with the software and hardware component. It will protect sensitive places from unwanted individuals or groups of individuals that usually take advantage of loose security systems from the entry point.

This paper introduces an alternative technique that employs easy-to-find instruments to develop the sanitization gates. This use sensor component is a PIR sensor, which is the main component that can read the movement of objects. Inside these components have also been assembled so that there is a timer for the duration of the sensor running and the sensitivity of the sensor. The choice of the PIR sensor is because it is more affordable and widely available on the marketplace.

\section{MATERIALS AND METHODS}

This research was conducted in July 2020. The planning was made on Jl Sirsak No41D Rt 08 Rw 07 Jagakarsa Village, Jagakarsa District, South Jakarta. This tool is installed in front of the side alley of the Jagakarsa sub-district. Below is a series of tools that have been made.

When viewed from the picture above the tools used in the study are:

1. The PIR sensor is used to find out if people are passing by on the road.

2. DC $12 \mathrm{~V}$ pump is used to distribute the disinfectant liquid in the container that has been provided

There are 3 cables or inputs on the sensor that function:

- The brown wire is a sensor input; this input serves as the input power needed to activate the sensor. The power required for this tool is $220 \mathrm{~V}$ / $5 \mathrm{~A}$, which is equivalent to home electricity.

- The red-wire is the input device to the sensor. That is to function as a sensor output in the form of a binary function that will activate a pump or other device to be activated when the sensor receives movement

- The blue wire is the ground sensor.

Apart from the two main components, there are other components. There is a sprayer mist or commonly known as watering plants. And a 3/8 in. as well as multiple hose connections.

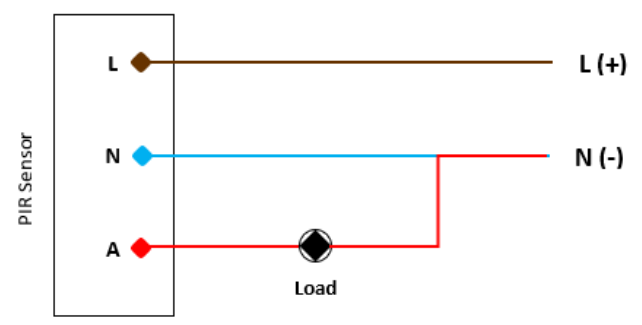

Figure 1. Circuit Diagram
To simplify the design, a work system flowchart is made. Figure 1 shows the program design that has been created with the following motion sensor specifications:

\section{Specification:}

- Detection Range: 1800

- Power Source: 220 - 240V/ AC

- Power Frequency: 50 / 60Hz

- Rated Load: Maximum.1200W (220 - 240V / AC) or $800 \mathrm{~W}(110-130 \mathrm{~V} / \mathrm{AC})$

- Source of sunlight $300 \mathrm{~W}(220-240 \mathrm{~V} / \mathrm{AC})$ $200 \mathrm{~W}(110-130 \mathrm{~V} / \mathrm{AC})$

- Light source lamp

- Detection Distance: $12 \mathrm{~m}$ max $(<240 \mathrm{C})$

- Time Delay: Min. $10 \mathrm{Sec} \pm 3 \mathrm{Sec}$ (Max. $7 \mathrm{~min} \pm 2$ $\min$ )

- Ambient light: <3 - 2000 LUX (adjustable)

- Installation height: $1.8-2.5 \mathrm{~m}$

- Detection Motion: $0.6-1.5 \mathrm{~m} / \mathrm{s}$

A sensor is a detection or sensing device that drives or regulates directly any deviation from a predetermined reference. An infrared motion sensor is a device composed of pyroelectric infrared (PIR) which is the main component of the device. The working system is when pyroelectric materials react to infrared radiation by generating electricity. There are various kinds of components, such as relays for converting AC to DC currents and various other components that are incorporated into the tool(Lady Ada, 2020).

When compared to other sensors, the operation of PIR sensors is unique and complicated. Many variables influence the sensors' input and output, which adds to the difficulty. Changes in the amount of infrared radiation incident on it are detected by the PIR sensors. The surface properties and temperature of the material in front of the sensor affect the IR radiations. The temperature of the region will change from room temperature to body temperature if some object, such as a human, moves in front of the PIR sensor. When the object has gone, the temperature will return to normal.

A pyroelectric sensor is an eye-like optical device that can "see" by detecting changes in infrared energy. This sensor consists of a special material in the form of a thin section called a pyroelectric ceramic. This material has many small crystals or dipoles, which are like tiny magnets floating randomly in a pyroelectric ceramic material. 


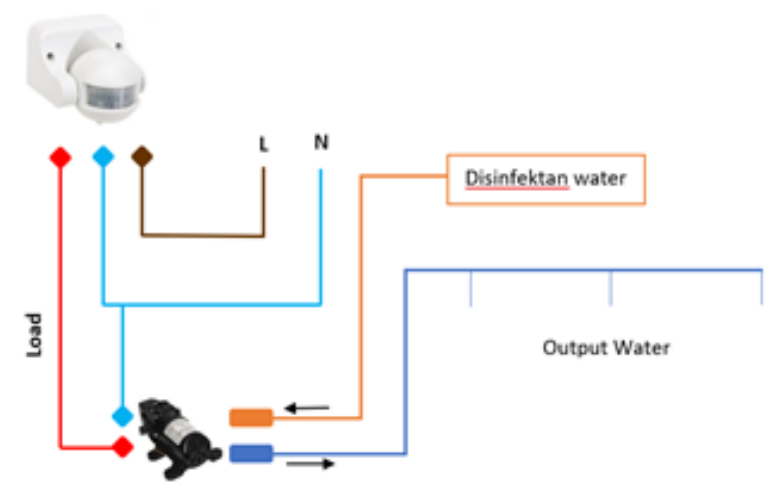

Figure 2. Gate Schematics

The schema of this works displayed in Figure 2 , in this work we used 12 DC pumps, in contrast to the pump in the house that requires large power and large pressure. The Dc pump is a low power pump with low pressure which functions to draw water, liquids, or all liquid ingredients. This pump is portable and can be used everywhere as needed.

The disinfectant fluid used is a product from Dettol $囚($ El Mahmood \& Doughari, 2008) which according to a study by the Indonesian Ministry of Health can kill bacteria and viruses on the surface. Due to the antimicrobial properties of chloroxylenol, the main chemical constituents of Dettol and other chlorinated phenols have been extensively studied and their antimicrobial disinfectant properties against several bacterial pathogens have previously been reported. The gate tool concept that will be implemented is shown in Figure 3.

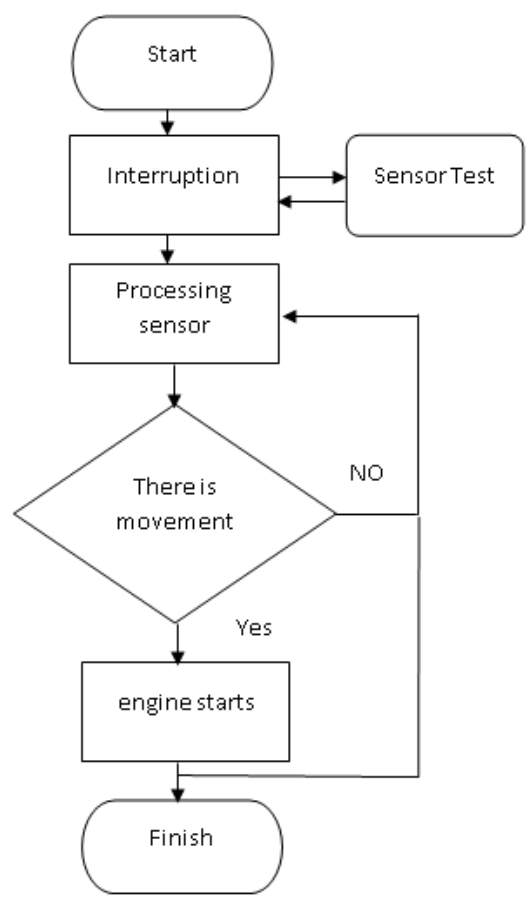

Figure 3. Flow Chart of The Gate Tool

\section{RESULTS AND DISCUSSION}

This tool is assembled and placed on the wall with a height of 1 meter above the ground. Then arranged as shown in Figure 4.

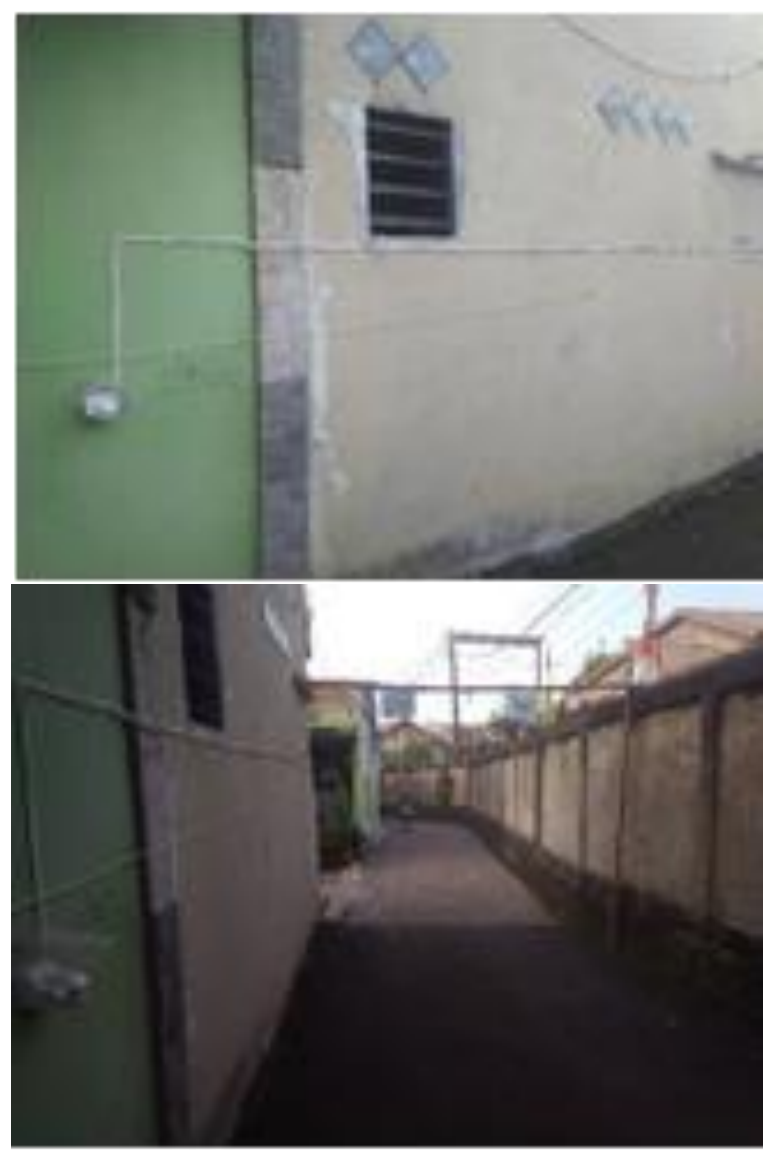

Figure 4. Sensor Position

The research From the tool connected by cable. The first wire is connected to power from electricity. The second cable is connected to a $12 \mathrm{~V}$ dc pump, as shown in Figure 5.
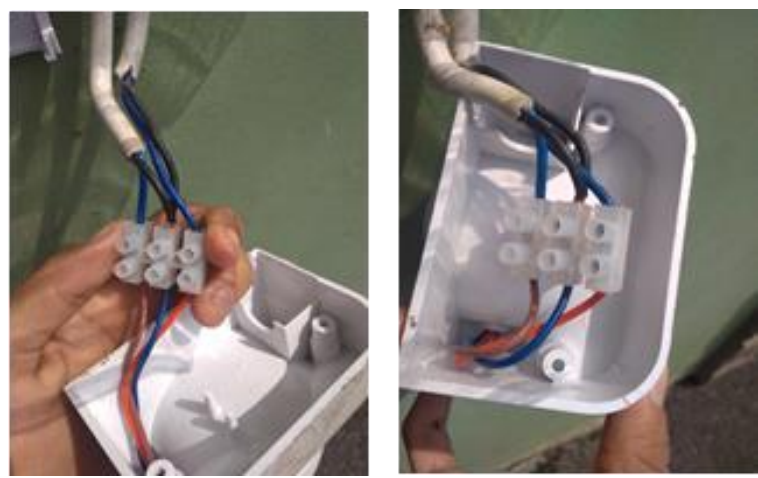

Figure 5. Installing a sensor with a pump

And after the sensors are installed, all the materials and tools are arranged as shown in Figure 6. 


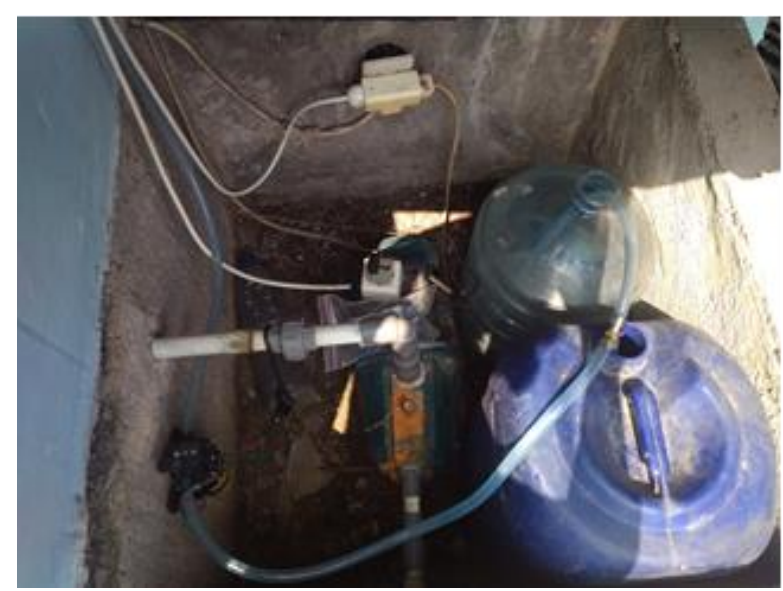

Figure 6. Installation of pumps, power, and disinfectant fluids

Then an experiment was carried out to start the tool by turning on the power. And the following results were obtained. Then a simulation is carried out if people are passing through the sensor.

When an individual enters through the gate, the disinfectant is sprayed on them for about 5 seconds by the spraying machine. The disinfectant would be sprayed in the form of a mist by spray nozzles in the spraying system. The aim is to improve the virus's ability to neutralize itself.

From the first simulation, the minimum time delay is set to obtain the following data, explained in Table 1.

Table 1. Sensor Delay Time

\begin{tabular}{lll}
\hline No. & Time $(\mathrm{s})$ & $\begin{array}{l}\text { Initial Distance } \\
(\mathrm{m})\end{array}$ \\
\hline 1 & 11.51 & 6 \\
2 & 11.51 & 6 \\
3 & 11.52 & 6 \\
4 & 11.52 & 6 \\
5 & 11.51 & 6 \\
6 & 11.50 & 6 \\
7 & 11.50 & 6 \\
8 & 11.51 & 6 \\
9 & 11.51 & 6 \\
10 & 11.51 & 6 \\
\hline Average & $\mathbf{1 1 . 5 1}$ & $\mathbf{6}$ \\
\hline
\end{tabular}

The initial distance is the distance from the person crossing until it is detected by the sensor. The time taken is the only minimal time because the maximum time is too long and consumes a lot of materials. This sensor has a range of 1800 and is effective if it detects horizontal movement from the direction of the sensor. And the sensors don't respond to any approaching vertically. From these data, it is found that the accuracy of the time obtained with the literature in the form of datasheets, which is equal to $100 \%$. The position of the sensor that is placed outside the room makes the sensor sensitive only in settings with medium brightness. Because the sensor receives enough light and is more sensitive when working in brighter light. The disinfectants used are always refilled at 17.00 WIB every day, it is replaced with new liquid.

\section{CONCLUSION}

We deploy the automatic sterilization gate tool using a motion sensor, to support the demand for these walkthrough gates that have arisen during the Covid-19 pandemic, this gate is affordable and the parts are widely available on the marketplace. The instrument has been running well and can be used for the common interest. The result of the minimum time accuracy of this tool is $100 \%$ of the data obtained This tool can not only detect humans but all objects that can change the variable sensor. Based on our experiments, the disinfectant fluid is always running out at 17.00 due to too high occupancy of the experiment area.

The automatic gate has helped the community to reduce the risk of transmission of the coronavirus, it also raises the awareness of the covid-19 pandemic. The gate is comfortable and easier to operate because it employs a sensor, rather than the usual manpower. The gate can be further improved by adding a scanning device to perform tracing for passersby.

\section{REFERENCES}

Asha, N., Syed Navaz, A. S., Jayashree, J., \& Vijayashree, J. (2018). Rfid based automated gate security system. Journal of Engineering and Applied Sciences, 13(22), 8901-8906.

Baskara, B. (2020, April 18). Rangkaian Peristiwa Pertama Covid-19. Kompas.Id, p. Kajian Data. Retrieved from https://www.kompas.id/baca/riset/2020/0 4/18/rangkaian-peristiwa-pertama-covid$19 /$

Buoite Stella, A., Ajčević, M., Furlanis, G., Cillotto, T., Menichelli, A., Accardo, A., \& Manganotti, P. (2020). Smart technology for physical activity and health assessment during COVID-19 lockdown. The Journal of Sports Medicine and Physical

Fitness.

https://doi.org/10.23736/S00224707.20.11373-2

El Mahmood, A. M., \& Doughari, J. H. (2008). Effect of Dettol ${ }^{\circledR}$ on viability of some microorganisms associated with nosocomial 
infections. African Journal of Biotechnology, 7(10), 1554-1562. Retrieved from https://www.ajol.info/index.php/ajb/article /view/58722

Florence Ikpeze, O., Chidiebere Uwaezuoke, E., Samiat, B.-M., \& Kareem, Michael, K. (2019). Design and Construction of an Automatic Gate. $A B U A D$ Journal of Engineering Research and Development, 2(2), 123-131.

Gardezi, A., Rathore, F. A., \& Farooq, F. (2020). Sanitization Walk-Through Gates During COVID-19 Pandemic: Effective or A false sense of protection? Annals of King Edward Medical University.

Gifson, A., \& Slamet, S. (2009). Sistem Pemantau Ruang Jarak Jauh Dengan Sensor Passive Infrared Berbasis Mikrokontroler AT89S52. TELKOMNIKA (Telecommunication Computing Electronics and Control), 7(3), 201-206. https://doi.org/10.12928/telkomnika.v7i3.5 95

Hadi, A. (2015). Design and Development of LowCost Auto Gate System for House, Part 4. In Https://www.researchgate.net/publication/ 289671529_Design_and_Development_of_Lo w_Cost_Auto_Gate_System_for_House_Part_4 (Ed.), 2nd Integrated Design Project Conference (IDPC) 2015 (pp. 1-10). Pahang: Universiti Malaysia Pahang.

Hamid, E., Gee, L. C., Bahaman, N., Anawar, S., Ayob, Z., \& Malek, A. A. (2018). Implementation of Intelligent Automated Gate System with QR Code-An IoT System to help gate management. International Journal of Advanced Computer Science and Applications. https://doi.org/10.14569/IJACSA.2018.0910 43

Khreasarn, K., \& Hantrakul, K. (2018). Automatic gate using Bluetooth technology (Open the gate with the strength of the Bluetooth signal on the smartphone). 3rd International Conference on Digital Arts, Media and Technology, ICDAMT 2018. https://doi.org/10.1109/ICDAMT.2018.8376 495

Lady Ada. (2020). PIR Motion Sensor. Retrieved from Adafruit Learning System website: https://cdn-

learn.adafruit.com/downloads/pdf/pirpassive-infrared-proximity-motionsensor.pdf
Lestari, N. (2017). Rancang Bangun Pintu Otomatis Menggunakan Arduino Uno Dan PIR (Passive Infra Red) Sensor Di SMP Negeri Simpang Semambang. Journal of Chemical Information and Modeling.

Maurya, D., Gohil, M. K., Sonawane, U., Kumar, D., Awasthi, A., Prajapati, A. K., ... Agarwal, A. K. (2020). Development of Autonomous Advanced Disinfection Tunnel to Tackle External Surface Disinfection of COVID-19 Virus in Public Places. Transactions of the Indian National Academy of Engineering. https://doi.org/10.1007/s41403-02000141-7

Morsalin, S., Islam, A. M. J., Rahat, G. R., Pidim, S. R. H., Rahman, A., \& Siddiqe, M. A. B. (2017). Machine-to-machine communication-based smart home security system by NFC, fingerprint, and PIR sensor with the mobile android application. 2016 3rd International Conference on Electrical Engineering and Information and Communication Technology, ICEEiCT 2016. https://doi.org/10.1109/CEEICT.2016.7873 048

Sukmana, H. T., Farisi, M. G., \& Khairani, D. (2016). Prototype utilization of PIR motion sensor for the real-time surveillance system and webenabled lamp automation. APWiMob 2015 IEEE Asia Pacific Conference on Wireless and Mobile.

https://doi.org/10.1109/APWiMob.2015.737 4968

Tavakoli, M., Carriere, J., \& Torabi, A. (2020). Robotics, Smart Wearable Technologies, and Autonomous Intelligent Systems for Healthcare During the COVID-19 Pandemic: An Analysis of the State of the Art and Future Vision. Advanced Intelligent Systems. https://doi.org/10.1002/aisy.202000071

Vasantharao, G., \& Arifunneesa, S. (2020). Temperature Detection and Automatic Sanitization and Disinfection Tunnel-COVID 19. The International Journal of Analytical and Experimental Modal Analysis.

WHO. (2020). Q\&A on coronaviruses (COVID-19). 